\title{
COMPARISON OF SEROLOGICAL METHODS FOR THE DIAGNOSTIC OF CAPRINE ARTHRITIS-ENCEPHALITIS (CAE) IN RIO DE JANEIRO, BRAZIL
}

\author{
Madelayne Cortez-Moreira ${ }^{1 *}$; Walter M.R. Oelemann' ${ }^{\text {; Walter Lilenbaum }}{ }^{2}$ \\ ${ }^{1}$ Laboratório de Imunodiagnóstico, Instituto de Microbiologia Prof. Paulo de Góes, Universidade Federal do Rio de Janeiro, \\ Rio de Janeiro, RJ, Brasil; ${ }^{2}$ Laboratório de Bacteriologia Veterinária, Instituto Biomédico, Universidade Federal Fluminense, \\ Rio de Janeiro, RJ, Brasil
}

Submitted: January 27, 2004; Returned to authors for corrections: August 26, 2004; Approved: March 28, 2004

\begin{abstract}
Serum samples of 562 goats were tested for Caprine arthritis-encephalitis using agar gel immunodiffusion test (AGID) and enzyme linked immunosorbent assay (ELISA). Seventy-nine samples (14.1\%) were reactive by both testes but $141(25.1 \%)$ were reactive only by ELISA. ELISA, when compared to AGID, presented 100\% sensitivity and $70.8 \%$ specificity.
\end{abstract}

Key words: Caprine arthritis-encephalitis, CAE, goats, ELISA, AGID

Caprine arthritis-encephalitis (CAE) is a debilitating and progressive disease caused by a lentivirus (CAEV) belonging to the Retroviridae family. The clinical manifestations include chronic synovitis and arthritis; demyelinizing encephalitis; chronic interstitial pneumonia; and acute or chronic mastitis, which greatly diminishes the milk production $(2,7)$.

CAE can affect animals of both sexes, of various different races, and at all ages. However, encephalitis occurs more frequently in young animals, while arthritis in more mature animals (2). The most important route of transmission is the nursing with virus containing milk or colostrum, but horizontal, vertical and venereal transmission, as well as transmission by contact with blood from infected animals are also possible $(1,9,12)$. Since there is no known cure for CAE and due to the economic losses, the prophylaxis of the disease, including the correct identification of infected animals, is extremely important (9).

The Office International des Epizooties (OIE) recommends for the diagnosis of CAE the virus isolation. However, this is time-consuming and not always successful. Thus, specific antibodies through serologic tests can be assayed. The two most commonly used tests are the agar gel immunodiffusion test (AGID) and the enzyme-linked immunosorbent assay (ELISA) (8).
Some controversy can be observed about which is the most reliable serodiagnostic method for CAE. In spite of the recommendation of several authors, who state that ELISA is a more reliable test due to its higher sensitivity $(3,10)$, and others who suggest a combination of the two tests for an accurate serological diagnostics (4), OIE sustains AGID as the prescribed test for CAE. Thus, the International Animal Health Code requires AGID for the testing of animals in connection with international trade. ELISA is considered by this organization as an alternative test that can also be used in the import/export of animals after bilateral agreement (8).

The main purpose of the present study was to compare the ELISA performance in relation to AGID for use as routine serodiagnostic test in Rio de Janeiro, Brazil.

We analyzed 562 serum samples obtained from goats older than 90 days, from farms located in the mountain region of Rio de Janeiro state. This region, due to its temperate climate, is the most traditional in goat breeding in Rio de Janeiro and represents about $60 \%$ of the dairy goat flocks in the state.

The commercial ELISA(ELISA Maedi-Visna/CAEV Serum Verification, version P032/01, Institute Pourquier, France) was carried out following the recommendations of the manufacturer. The test uses as antigen the p28 recombinant viral capside protein adsorbed to the wells of polystyrene microtiter plates.

*Corresponding Author. Mailing address: Rua Major Ávila, 200/801, Tijuca. 20511-140, Rio de Janeiro, RJ, Brasil. E-mail: madelaynecortez@yahoo.com.br 
Positive and negative control sera were also provided, as well as a conjugate consisting of a monoclonal antibody specific for caprine and ovine immunoglobulin $\mathrm{G}$ (IgG) linked to horseradish peroxidase. Test results were read at $450 \mathrm{~nm}$.

The commercial AGID (AGID-CAEV p28; Institute Pourquier, France) was carried out in Petri dishes in agarose gels containing seven equidistant holes of the same size (one central and six peripheral). The samples, the positive control serum and the recombinant p28 antigen were loaded into these wells, and the dish was subsequently incubated in a humid chamber at $25^{\circ} \mathrm{C}$. Results were read after 96 hours. Samples were considered reactive when a precipitation line appeared between the wells containing the serum and the antigen.

Of the 562 tested serum samples, 342 (60.8\%) were negative both by AGID and ELISA (Table 1) and considered as nonreactive. Seventy-nine samples $(14.1 \%)$ were reactive in both assays and therefore considered positive. These results suggest a relatively high occurrence of CAE in the tested region of Rio de Janeiro state. This finding is in agreement with other studies conducted in Rio de Janeiro (5) and other states of Brazil (11).

Nevertheless, 141 samples $(25.1 \%)$ presented discordant results, being positive only by ELISA, indicating the higher sensitivity of ELISA (Table 1). No ELISA negative sample was reactive by AGID. All samples with discordant results were retested by both tests. Differences between results by the two tests were highly significant $(\mathrm{p}<0.0001)$. In relation to AGID, sensitivity of ELISA was calculated as $100 \%$ and specificity as $70.8 \%$.

Table 1. Comparison of ELISA and AGID results on 562 goat serum samples of Rio de Janeiro state, Brazil.

\begin{tabular}{lccc}
\hline & AGID positive & AGID negative* & Total \\
\cline { 2 - 4 } ELISA positive* & 79 & $141^{*}$ & $\mathbf{2 2 0}$ \\
ELISA negative & 0 & 342 & $\mathbf{3 4 2}$ \\
\hline Total & $\mathbf{7 9}$ & $\mathbf{4 8 3}$ & $\mathbf{5 6 2}$ \\
\hline
\end{tabular}

* No ELISA negative sample was reactive by AGID.

In order to investigate the occurrence of delayed seroconversion, new samples were collected from these goats with discordant results after six months and re-tested by both tests. The totality of these animals remained negative by AGID. Unfortunately, no attempt was made in order to isolate CAEV and the real status of the infection on these animals remains uncertain.

The higher sensitivity of ELISA and its great ability in detecting even small amounts of antibodies are well known and unquestionable. Nevertheless, the correct determination of the real status of the animal is complex and may require a combination of serology and clinical evaluation. According to OIE, the AGID is specific and remains the most frequently used test, due to its high performance (8).

In the present study, all ELISA-reactive animals that were AGID negative confirmed the results after six months. This was an unexpected finding, since delayed seroconversion detectable by AGID could characterize ELISA as the most reliable and early serodiagnostic method. Nevertheless, in face of the absence of seroconversion of those animals and considering the OIE prescription for AGID, the possibility of occurrence of false-positive reactions in ELISA shall be considered.

ELISA can be a very useful tool for the rapid screening of anti-CAEV antibodies in goats. It is economical and the process can be automated, thus making it convenient for screening large number of sera. Its application in a two-step protocol, with confirmation of reactive samples by AGID, would simplify the diagnosis of the disease in large flocks and is highly recommendable. Nevertheless, we believe that, due to its low specificity when compared to the OIE prescribed test and the possibility of the occurrence of false-positive reactions, further studies are necessary before the test is routinely adapted as the only reliable serological test for the diagnosis of Caprine arthritis-encephalitis (CAE) in Rio de Janeiro, Brazil.

\section{ACKNOWLEDGEMENTS}

MCM is MSc fellow funded by the Conselho Nacional de Pesquisa (CNPq). WMRO and WL are research fellows of CNPq. Financial support was also provided by Fundação de Amparo à Pesquisa Carlos Chagas Filho, FAPERJ. The authors are thankful to Dr. P. Cordeiro and Dr. C. Pizzarro as well as to the students Y.N.P. Gomes and R.G. Varges. They are also thankful to Pourquier Lab., France for kindly providing the kits.

\section{RESUMO}

\section{Comparação entre métodos sorológicos para o diagnóstico da Artrite-encefalite caprina (CAE) no Rio de Janeiro, Brasil}

Soros de 562 caprinos foram submetidos à pesquisa de Artrite-encefalite caprina através dos testes de imunodifusão em gel de agarose (AGID) de teste imunoenzimático (ELISA). Das amostras testadas, $79(14,1 \%)$ foram reativas em ambos os testes, mas $141(25,1 \%)$ foram positivos apenas no ELISA. Assim, a sensibilidade do ELISA em relação ao AGID foi de $100 \%$ e a especificidade de $70,8 \%$.

Palavras-chave: Artrite-encefalite caprina, CAE, caprinos, ELISA, AGID 


\section{REFERENCES}

1. Adams, D.S.; Klevjer-Anderson, P.; Carlson, J.L., Mcguire, T.C.; Gorham, J.R. Transmission and control of caprine arthritisencephalitis virus. Am. J. Vet. Res., 44, 1670-75, 1983.

2. Callado, A.K.C.; Castro, R.S.; Teixeira, M.F.S. Lentiviruses of small ruminants (CAEV e Maedi-Visna): a review and perspectives. Pesq. Vet. Bras., 21(3), 87-97, 2001.

3. Castro, R.S.; Leite, R.C.; Resende, M.; Gouveia, A.M. A labelled avidinbiotin ELISA to detect antibodies to caprine arthritis-encephalitis virus in goats' sera. Vet. Res. Commun., 23(8), 515-22, 1999.

4. Celer, V. Jr.; Celer, V.; Nemcova, H.; Zanoni, R.G.; Peterhans, E. Serologic diagnosis of ovine lentiviruses by whole virus ELISA and AGID test. Zentralbl Veterinarmed B., 45(3), 183-8, 1998.

5. Cunha, R.G.; Nascimento, M.D. Antibodies occurrence to caprine arthritis-encephalitis virus in goat sera from Rio de Janeiro State (Brazil). Rev. Bras. Med. Vet., 17(2), 72-75, 1995.

6. Galen, R.S.; Gambino, S.R. Beyond Normality: The Predictive Value and Efficiency of Medical Diagnosis, (John Wiley \& Sons, New York). 1975.
7. Narayan, O.; Clements, J.E. Biology and pathogenesis of Lentiviruses. J. Gen. Virol., 70, 1617-1639, 1989.

8. OIE. Office International Des Epizooties. Manual of standards Diagnostic Tests and Vaccines 2000. Updated: 22.04.2002. http:// www.oie.int/eng/normes/mmanual/ancien_manuel/a_00065.htm

9. Phelps, S.L.; Smith, M.C. Caprine arthritis encephalitis virus infection. J. Am. Vet. Med. Ass., 203(12), 1663-6, 1993.

10. Rosati, S.; Kwang, J.; Tolari, F.; Keen, J. A comparison of whole virus and recombinant transmembrane ELISA and immunodiffusion for detection of ovine lentivirus antibodies in Italian sheep flocks. Vet. Res. Commun., 18(1), 73-80, 1994.

11. Saraiva Neto, A.O.; Castro, R.S.; Birgel, E.H.; Nascimento, S.A. Sero-epidemiological survey on caprine arthritis encephalitis in Pernambuco, Brazil. Pesq. Vet. Bras., 15(14), 121-4, 1995.

12. Travassos, C.E.P.F.; Silva, A.G.; Perrin, G. Detection of caprine arthritisencephalitis virus as cell-free virus in semen from seropositive bucks. R. Bras. Ci. Vet., 6(1), 36-39, 1999. 